\title{
NEW LOCALITY FOR NOTOCHTHAMALUS SCABROSUS (CRUSTACEA, CIRRIPEDIA): BAHÍA LAPATAIA, BEAGLE CHANNEL, TIERRA DEL FUEGO, ARGENTINA.
}

\author{
NUEVA LOCALIDAD PARA NOTOCHTHAMALUS SCABROSUS (CRUSTACEA, \\ CIRRIPEDIA): BAHÍA LAPATAIA, CANAL BEAGLE, TIERRA DEL FUEGO, ARGENTINA. \\ Jessica Curelovich ${ }^{1}$, Gustavo A. Lovrich ${ }^{2} \&$ Javier A. Calcagno ${ }^{1}$
}

Notochthamalus scabrosus (Darwin, 1854) is commonly attached to littoral rocks and shells, often associated with Notobalanus flosculus (Darwin, 1854), and sometimes with Chthamalus cirratus (Darwin, 1851). Notochthamalus scabrosus was previously reported from Peru to Tierra del Fuego and Islas Malvinas / Falkland Islands by Darwin (1851). Moreover, the review of South American barnacle distribution by Young (1995) suggested that the temperate zone of the Southwestern Atlantic, occurring between $35^{\circ} \mathrm{S}$ and the southern tip of South America (56ㅇ), had a barnacle fauna similar to that of the Southeastern Pacific (coasts of Chile and Peru), with $N$. scabrosus occurring at both zones. Particularly in the Beagle Channel, $N$. scabrous is the dominant species in the upper zone of the rocky intertidal.

The Beagle Channel is located at the southernmost tip of South America (ca. 55응 S; $68^{\circ} \mathrm{W}$ ) and is an ancient glacial valley of about $210 \mathrm{~km}$ length and $5 \mathrm{~km}$ width, with different basins. The Beagle Channel has fjord estuarine features with salinities lower than the surrounding oceanic water masses due to the discharge of glaciers and rivers (Balestrini et al. 1998, Isla et al. 1999). One of these subsystems is the estuarine complex of Lago Roca-Bahía Lapataia, a palaeo-fjord currently constituted by a lake discharging freshwater to the channel via the Ovando River (Isla et al. 1999; Fig. 1).

Zaixso et al. (1978) described the rocky intertidal flora and fauna from 11 localities at the Beagle Channel. N. scabrosus was reported by the authors from three localities: Bahía Ensenada (Ensenada

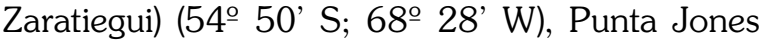
(54 $49^{\prime} \mathrm{S} ; 6^{\circ}$ 13' W) and Bahía Ushuaia (54º 49' S; 68 19' W). With regard to Bahía Lapataia, Zaixso et al. (1978) mentioned that this species was absent there, likely as a consequence of the low salinity characterizing the zone. Authors reported the presence of Elminius kingii (Gray 1831) as the only barnacle species for this location.

In the present study we report for the first time the presence of $N$. scabrosus in the upper zone of the rocky intertidal of the western coast

1 Facultad de Ciencias Exactas y Naturales - Universidad de Buenos Aires - CONICET, Ciudad Universitaria, C1428EHA, Buenos Aires. Argentina

2 Centro Austral de Investigaciones Científicas (CADIC-CONICET), Houssay 200, V9410CAB, Ushuaia, Tierra del Fuego. Argentina 


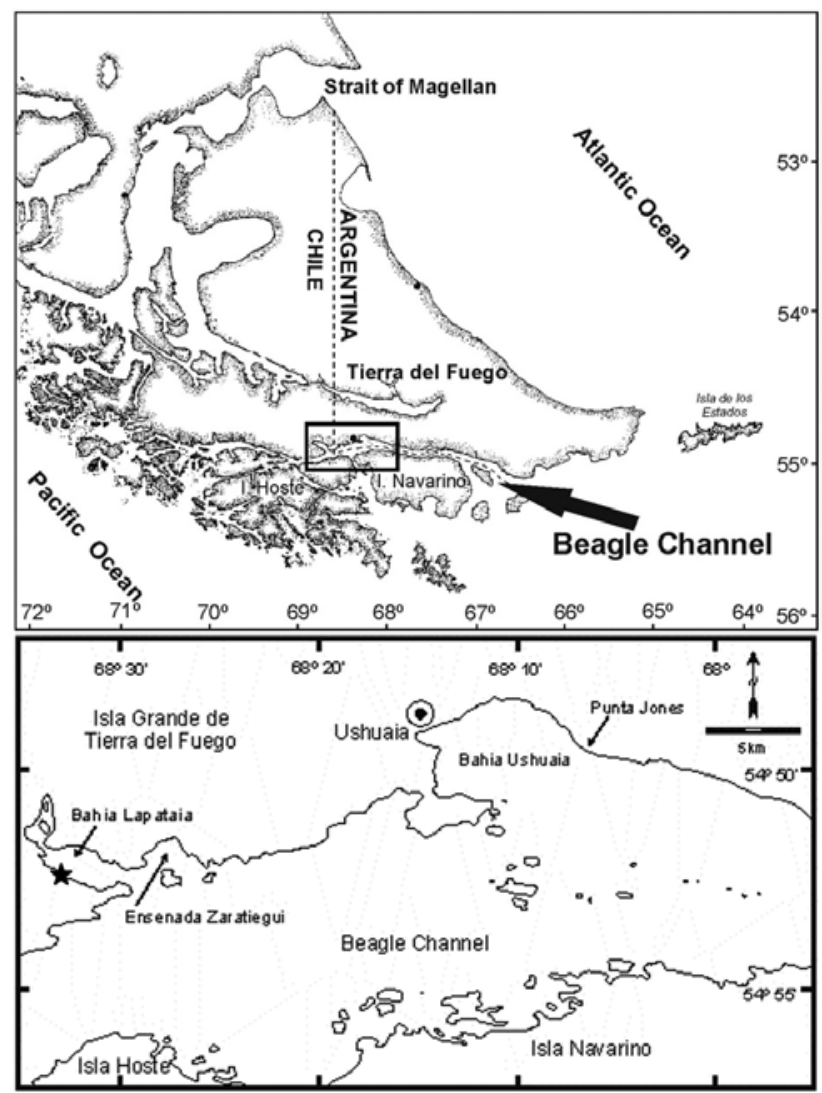

Fig. 1. Geographical situation of the area. $\star$ First record of N. scabrosus from Bahía Lapataia.

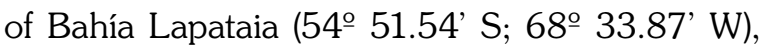
Tierra del Fuego (Fig. 1). Specimens of N. scabrosus were found along with Elminius kingii (Fig. 2). On September $25^{\text {th }}, 2008$ photographs and samples of

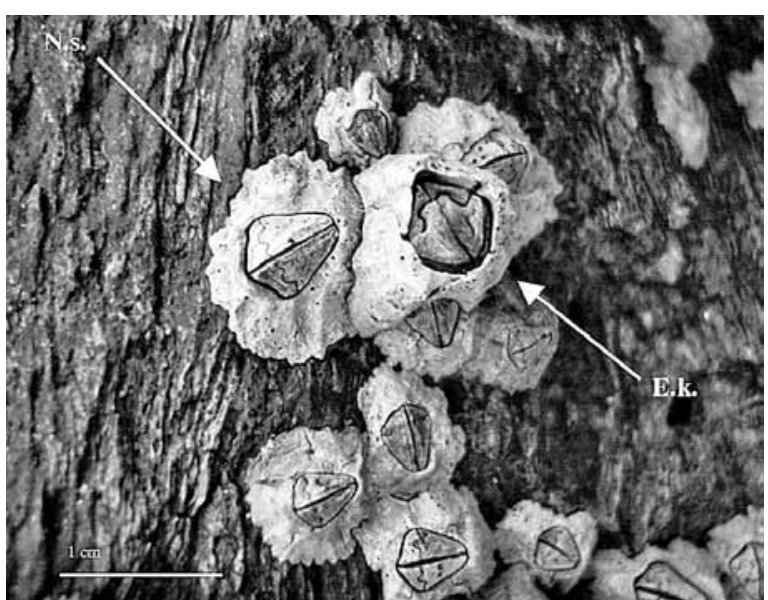

Fig. 2. Notochthamalus scabrosus (N.s.) and Elminius kingii (E.k.) found in the western coast of Bahía Lapataia, Tierra del Fuego, Argentina. both species were taken. The samples were collected for accurate identification after dissection.

Especially during spring and summer, Ensenada Zaratiegui and Bahía Lapataia have very variable and lower salinity than other sites of the Beagle Channel, which in turn are less influenced by freshwater discharges (Table 1). N. scabrous is clearly a euryhaline species since specimens can tolerate a range of salinities of $15-31$ ups. Although there are no specific studies on salinity tolerance of this species, the genus Chthamalus is known to be euryhaline (e.g. Crisp \& Costlow 1963, López \& González 2003, Farrapeira 2008).

Roughgarden et al. (1988) and Alexander \& Roughgarden (1996) have suggested that the ecology of a rocky intertidal community at a site would be governed by adult-adult interactions within the site, or by limitations to the supply of larvae reaching the site, the latter being determined by the regional pattern of circulation and physical oceanography in the coastal waters. These characteristics would explain 
TABLE 1. Surface salinity from different localities of the Beagle Channel obtained with a multiparameter meter.

\begin{tabular}{|c|c|c|c|c|}
\hline \multirow[t]{2}{*}{ Locality } & \multirow[t]{2}{*}{ Latitude } & \multirow[t]{2}{*}{ Longitude } & \multicolumn{2}{|c|}{ Salinity (UPS) } \\
\hline & & & Summer & Winter \\
\hline \multirow[t]{2}{*}{ Ensenada Zaratiegui } & $54^{\circ} 50.86^{\prime} \mathrm{S}$ & $68^{\circ} 28.79^{\prime} \mathrm{W}$ & $15.0^{\mathrm{b}}-19.4^{\mathrm{a}} *$ & nd \\
\hline & $54^{\circ} 50.92^{\prime} \mathrm{S}$ & $68^{\circ} 28.96 \mathrm{~W}$ & $23.9^{\mathrm{c}}-25.0^{\mathrm{d}}$ & 30.8 \\
\hline \multirow[t]{3}{*}{ Bahía Lapataia } & $54^{\circ} 51.32^{\prime} \mathrm{S}$ & $68^{\circ} 34.39^{\prime} \mathrm{W}$ & $20.1^{\mathrm{a}}-31.7^{\mathrm{b} *}$ & nd \\
\hline & $54^{\circ} 51.62^{\prime} \mathrm{S}$ & $68^{\circ} 33.44^{\prime} \mathrm{W}$ & $29.0^{c}-31.0^{d}$ & 31.2 \\
\hline & $54^{\circ} 51.17^{\prime} \mathrm{S}$ & $68^{\circ} 33.87^{\prime} \mathrm{W}$ & $21.7^{c}-25.5^{d}$ & 31.7 \\
\hline Beagle Channel & $54^{\circ} 50.89^{\prime} \mathrm{S}$ & $68^{\circ} 15.83^{\prime} \mathrm{W}$ & $31.3^{d}-31.5^{c}$ & 31.3 \\
\hline
\end{tabular}

References: * Data from Isla et al. (1999). a: 22 february 1998, b: 25 february 1999, c: November 2006, d: March 2006; nd: no data available.

the variation of timing of recruitment at the coast and the likely reason that it occurs in discrete pulses.

We propose that the establishment of $N$. scabrosus in Bahía Lapataia could be a consequence of local hydrological events, namely coastal currents, wind direction and intensity and availability of larvae in the plankton rather than by the low saline waters characterizing the zone, and these events would explain the discontinuous scheme of distribution of $N$. scabrosus along the coast of the Beagle Channel. This channel is a particular environment because of its fjord features and its semi-closed condition (Antezana 1999). For example, the freshwater input may change the environmental conditions at a geographical micro-scale. In some western coves the ice input from glaciers may produce the typical coastal disturbance so that the intertidal community may be locally impoverished or absent (c.f. Mutschke \& Gorny 1999, Barnes 2005). Hence, the presence of certain species at different sites with both different freshwater input and coastal orientation -and therefore differentially affected by winds and currents- may be indicators of specific hydrological processes acting on the community structure and/ or diversity.

\section{ACKNOWLEDGMENTS}

Funded by Parque Nacional Tierra del Fuego, Universidad Nacional de la Patagonia San Juan Bosco-Ushuaia and Agencia Nacional de Promoción Científica y Tecnológica (PICT 06-1385). We would like to thank Lic. Gastón Aguirre for provision of salinity data and Dr. Eduardo Spivak for his help in the identification of barnacle species.

\section{LITERATURE CITED}

Alexander, S. \& J. Roughgarden 1996. Larval transport and population dynamics of intertidal barnacles: a coupled benthic/oceanic model. Ecological Monographs 66(3): 259-275.

Antezana, T. 1999. Hydrographic feature of Magellan and Fuegian inland passages and adjcent subantarctic waters. Scientia Marina 63 (suppl. 1)(1): 1-16.

Balestrini, C., G. Manzella \& G. A. Lovrich 1998. Simulación de corrientes en el Canal Beagle y Bahía Ushuaia, mediante un modelo bidimensional. Servicio de Hidrografía Naval. Departamento de Oceanografía. Informe Técnico 98, 58 pp.

Barnes, D. K. A. 2005. Changing chain: past, present and future of the Scotia Arc's and Antarctica's shallow benthic communities. Scientia Marina 69(suppl. 2): 65-89.

Crisp, D. J. \& J. D. Costlow Jr. 1963. The tolerance of developing cirripede embryos to salinity and temperature. Oikos 14(1): 22-34.

Darwin, C. 1851. A Monograph on the Subclass Cirripedia, with figures of all the species. The Lepadidae; or pedunculate cirripedes. Royal Society of London, $400 \mathrm{pp}$.

Farrapeira, C. M. R. 2008. Cirripedia Balanomorpha of Paripe River estuary (Itamaracá Island, Pernambuco, Brazil). Biota Neotropical 8(3): 031-039.

Isla F., G. Bujalesky \& A. Coronato 1999. Procesos estuarinos en el canal Beagle, Tierra del Fuego. Revista de la Asociación Geológica Argentina 54(4): 307-318. 
López, D. A. \& M. L. González 2003. Densitydependent effects in Jehlius cirratus (Darwin, 1854) (Cirripedia: Chthamalidae) under different growth conditions. Marine Ecology 24 (4): $289-302$.

Mutschke, E. \& M. Gorny 1999. The benthic decapod fauna in the channels and fjords along the South Patagonian Icefield, Southern Chile. Scientia Marina 63 (suppl. 1): 315-319.

Roughgarden, J., S. Gaines \& H. Possingham 1988. Recruitment Dynamics in Complex Life Cycles. Science 241(4872): 1460-1466.
Young, P. 1995. New interpretations of South American patterns of barnacle distribution. In: F. R. Schram \& J. T. Høeg (eds.). New frontiers in barnacle evolution. Crustacean Issues 10: 229-253.

Zaixso H. E., A. L. Boraso de Zaixso \& J. J. López Gappa 1978. Observaciones sobre el mesolitoral rocoso de la zona de Ushuaia (Tierra del Fuego, Argentina). Ecosur 5(10): 119-130. 